Bıochimica et Biophysica Acta, 658 (1981) 280-290

(C) Elsevier/North-Holland Biomedical Press

BBA 69232

\title{
CHARACTERISTICS OF AN AMINOHYDROLASE DISTINCT FROM ADENOSINE DEAMINASE IN CULTURED HUMAN LYMPHOBLASTS
}

\section{PETER E DADDONA and WILLIAM N KELLEY}

Departments of Internal Medicine and Btological Chemistry, Human Purine Research Center, The University of Michigan Medical School Ann Arbor, MI 48109 (US A)

(Received September 29th, 1980)

Key words Adenosine deaminase, ery thro-9-(2-Hydroxy-3-nonyl)adenine (Human B-lymphoblast cell)

\section{Summary}

An inhented deficiency of adenosine deaminase (adenosine aminohydrolase, EC 3.5.4.4) is associated with an autosomal recessive form of severe combined immunodeficiency disease. Affected patients exhibit markedly reduced or absent adenosine deaminating activity in vanous tissues. In this study we have demonstrated the presence of a low level aminohydrolase activity in 11 different normal and adenosine deaminase-deficient lymphoblast cell lines which is apparently distinct from normal adenosine deaminase. Based on enzymatic, physical and immunoreactive properties, this lymphoblast aminohydrolase does not appear to be related to adenosine deaminase and is most likely coded for by a different gene locus. In future investigations designed to charactenze mutant forms of adenosine deaminase, it will be important to distinguish this lymphoblast aminohydrolase activity from putative products of the adenosine deaminase gene locus.

\section{Introduction}

Adenosine deaminase (adenosine amınohydrolase, EC 3.5.4.4) catalyzes the conversion of either adenosine or deoxyadenosine to produce inosine and deoxyinosine, respectively, with the liberation of ammonia. The discovery of a deficiency of adenosine deaminase in some patients with an autosomal recessive form of severe combined immunodeficiency disease has provided an important clue to the pathogenesis of immune dysfunction at the molecular level [1-6]. 
A charactenzation of the residual adenosine deaminase activity in patients with adenosine deaminase deficiency and severe combined immunodeficiency disease has been difficult due to the extremely limited amount of enzyme activity expressed in vanous tissues of these patients. Further, any interpretation of the nature of the genetic heterogeneity of adenosine deaminase in these patients could be complicated without a complete understanding of the molecular and electrophoretic heterogeneity of the enzyme expressed in normal human tissues [7-10]. Recent studies have shown that human adenosine deaminase exists either as a 'particulate' species or as one of two soluble molecular forms, designated small form $\left(M_{\mathrm{r}} 38000\right)$ and large form $\left(M_{\mathrm{r}} 298000\right)$, which are interconvertible [10]. The small form of the enzyme from human erythrocytes is a single polypeptide exhibiting multiple electrophoretic forms anising from post-translational modification of a single gene product. In part, this heterogeneity may be due to sulfhydryl group modification on the enzyme [11-15]. The large molecular form of adenosine deaminase $\left(M_{\mathrm{r}} 298000\right)$ is composed of two molecules of small-form adenosine deaminase $\left(M_{\mathrm{r}} 38000\right)$ and one molecule of a specific adenosine deaminase-binding protein $\left(M_{\mathrm{r}} 213000\right)$ (also termed conversion factor or complexing protein) [16-18]. The large form of the enzyme also exists as 'tissue specific' electrophoretic vanants. These vanants appear to be generated by heterogeneity in the carbohydrate portion of the binding protein and are not due to additional variation in the small-form deaminase present in the complex [19].

Early studies of adenosine deaminase molecular heterogeneity indicated the presence of a low level of an 'intermediate' form of the enzyme $\left(M_{r} 110000\right)$ in a variety of human tissues [10]. In addition, analysis of splenic tissue from a patient with adenosine deaminase deficiency and severe combined immunodeficiency disease revealed that the molecular form of adenosine deaminase was exclusively the 'intermediate' species [20]. Subsequently, Schrader et al. [21] demonstrated that an 'aminohydrolase' intermediate in molecular weight between large- and small-form adenosine deaminase existed in normal spleen as well as in splenic tissue of another patient with adenosine deaminase deficiency and immune dysfunction. This splenic 'aminohydrolase' appeared to be different from normal adenosine deaminase based on $K_{\mathrm{m}}$ value, immunoreactivity, $\mathrm{pH}$ optımum and insensitivity to the potent adenosine deaminase inhibitor, EHNA. It has not been established, however, whether this low level of 'aminohydrolase' activity studied in these two subjects (a) arose from adenosine deaminase degradation durng post-mortem tissue autolysis, (b) represented a modified product of the adenosine deaminase gene locus, or (c) was a universal finding in viable human cells.

In this study, we have demonstrated the presence of an aminohydrolase in 11 different normal and adenosine deaminase-deficient B-lymphoblast cell lines which appears similar to the splenic aminohydrolase. An analysis of the enzymatic, physical and immunoreactive properties of the lymphoblast aminohydrolase suggests that this enzyme is distinct and not related to adenosine deamlnase 


\section{Materials and Methods}

$\left[8{ }^{14} \mathrm{C}\right]$ Adenosine $(59 \mathrm{mCl} / \mathrm{mmol})$ and $\left[\mathrm{U} \cdot{ }^{14} \mathrm{C}\right]$ deoxyadenosine $(500 \mathrm{mCl} /$ $\mathrm{mmol}$ ) were obtained from Amersham/Searle erythro-9-(2-Hydroxy-3-nonyl) adenine (EHNA) was a generous gift from Burroughs Wellcome, whlle 2'-deoxycoformycin was generously provided by Parke Davis, A Division of Warner/ Lambert. The adenosine deaminase-binding protein was purified to homogeneity from human kıdney as previously described [17]. All other chemicals and reagents used were of the highest quality commercially avalable. Normal B-lymphoblast cell lines (GM 130, GM 131, GM 333, GM 621, GM 1078 and MGL-8) and adenosine deaminase-deficient B-lymphoblast cell lines (GM 2471, GM 2606, GM 2294, GM 2445 and GM 2756 transformed from lymphocytes of patients with adenosine deaminase deficiency) were obtaned from the Human Genetic Mutant Cell Repository, Camden, NJ.

All lymphoblast cell lines were cultured in RPMI medium supplemented with $10 \%$ adenosine deaminase-deficient fetal calf serum. Adenosine deaminasedeficient fetal calf serum was prepared by passing unaltered fetal calf serum (Grand Island Biological Co.) through an anti-adenosine deaminase-IgG affinity column, prepared as previously described [22]. Fetal calf serum recovered as the column filtrate had less than $1 \%$ of the onginal adenosine deaminase present in untreated fetal calf serum and had no detectable 'aminohydrolase' activity. Cultured lymphoblasts were harvested in log phase of growth, washed twice with phosphate-buffered salıne (50 $\left.\mathrm{mM} \mathrm{NaHPO}_{4}, \mathrm{pH} 7.4 / 154 \mathrm{mM} \mathrm{NaCl}\right)$, and lyzed by repeated freeze-thawng. The crude cell extracts were dialyzed 1-1000 (v/v) in $10 \mathrm{mM}$ Tris- $\mathrm{HCl}, \mathrm{pH} 7.4 / 154 \mathrm{mM} \mathrm{NaCl}$ (buffer A) Membranefree cell extracts were prepared by centrifugation of crude cell lysates for 20 min at $100000 \times g$ in a Beckman aurfuge.

Adenosine deaminating activity in lymphoblast extracts was assayed by a radiochemical technique previously described [20]. Assay conditions utilized $\left[8 .{ }^{14} \mathrm{C}\right.$ ]adenosine $(2 \mathrm{mCl} / \mathrm{mmol})$ at a final adenosine concentration of $4 \mathrm{mM}$ (high adenosine reaction mixture). A similar reaction mixture was also prepared using $\left[\mathrm{U}-{ }^{14} \mathrm{C}\right]$ deoxyadenosine as substrate.

The molecular forms of adenosine deaminating activity in lymphoblast cell extracts were analyzed and isolated by sucrose gradient ultracentrifugation, using a previously described technique [10]. Cell extracts were applied to isokinetıc sucrose gradients (10-28.2\%) and centrnfuged for $40 \mathrm{~h}$ at $34000 \mathrm{rev}$./ min using a Spinco SW41 rotor in a Beckman Model L5-50 ultracentrifuge. Sucrose gradients were fractionated and assayed for adenosine deaminating activity using the high adenosine concentration reaction mixture. Fractions containing adenosine deamınating actıvity were pooled, dialyzed in buffer $\mathbf{A}$ $(1-1000, v / v)$ and concentrated on a Diaflo ultrafiltration system with a PM10 membrane (Amicon Corp., Lexington, MA).

The procedures for the determination of apparent substrate specificity, $\mathrm{pH}$ optımum, $K_{\mathrm{m}}$ value and heat stability of adenosine deamınating actıvity have been previously reported $[10,15]$. Molecular weights were determined by sucrose gradient ultracentrifugation using the method of McCarty et al. [23].

The concentration and relative affinity of immunoreactive adenosine deaminase protein and the adenosine deaminase-binding protein in lymphoblast 
cell extracts was quantified using previously described radioimmunoassay techniques [22,24]. Protein concentration was determined by the method of Lowry et al. [25] using bovine serum albumin as standard.

\section{Results}

Extracts from a normal B-lymphoblast cell line (MGL-8) and an adenosine deaminase-deficient B-lymphoblast cell line (GM 2445) were analyzed for adenosine deaminating activity after sucrose gradient ultracentrifugation. As shown in Fig. 1A, when sucrose gradient fractions were assayed with a high concentration of adenosine in the reaction mixture, as described in Matenals and Methods, a predominant peak of adenosine deaminating activity was observed at $s_{20, w} 3.8 \mathrm{~S}$ (fraction 28) simular to normal small-form adenosine deaminase $\left(M_{\mathrm{r}} 38000\right)$ [10,15]. In addition, a minor peak of adenosine deaminating activity was also present at an $s_{20, w}$ of $7.4 \mathrm{~S}$ (fraction 15). When the sucrose gradient fractions were assayed for adenosine deaminating activity in the presence of $200 \mu \mathrm{M}$ EHNA, enzyme activity in the predominant peak $\left(s_{20, w} 3.8 \mathrm{~S}\right)$ was completely inhibited, while greater than $90 \%$ of the activity in the smaller peak $\left(s_{20, w} 7.4 \mathrm{~S}\right)$ was retained $(\mathrm{Fig}, 1 \mathrm{~A})$. A simular analysis of the adenosine deaminase-deficient B-lymphoblast cell line, GM 2445, (Fig. 1B) revealed that virtually all of the adenosine deaminating activity present in this cell line exhibited an $s_{20, w}$ of $7.4 \mathrm{~S}$ and was insensitive to inhibition with EHNA. When the activity with an $s_{20, w}$ of $7.4 \mathrm{~S}$ was isolated from either normal or adenosine deaminase-deficient lymphoblast cell extracts by sucrose gradient
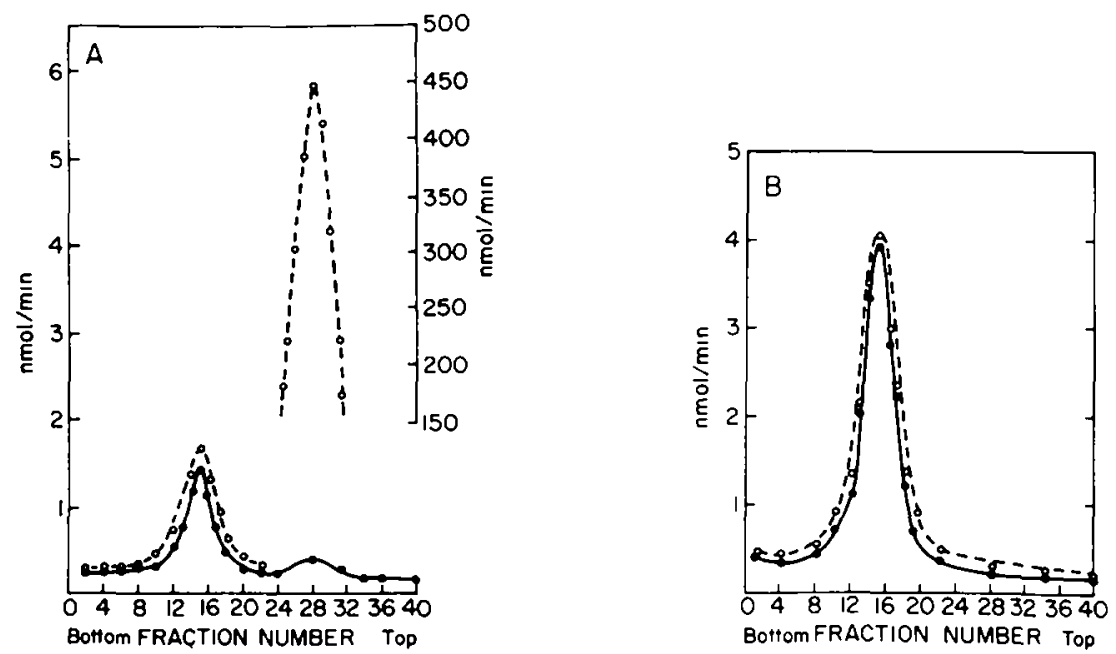

Fig 1 Sucrose density ultracentrifugation of adenosine deaminating activity in human Bdymphoblast cell extracts Cell extracts were prepared by freeze-thawing cells five times followed by centrifugation at $100000 \times g$ The soluble preparation was then applied to an isokinetic sucrose gradient $(10-28.29)$ and centrifuged at $4^{\circ} \mathrm{C}$ for $40 \mathrm{~h}$ at $34000 \mathrm{rev} / \mathrm{min}$ with a Spinco SW41 rotor in a Beckman model L5-60 ultracentrifuge Fractions were collected and assayed for adenosine deaminating activity using [14 C]adenosine $\left(2 \mathrm{mC}_{1} / \mathrm{mmol}, 4 \mathrm{mM}\right)$ reaction mixture $(O-O)$ and reaction mixture contaning $200 \mu \mathrm{M}$ EHNA (•-—) A Normal B-lymphoblast cell extract, MGL-8 B Adenosine deaminase-deficient BHymphoblast cell extract, GM 2445 
TABLE I

ADENOSINE DEAMINATING ACTIVITY IN NORMAL AND ADENOSINE DEAMINASE-DEFICIENT B-LYMPHOBLAST CELL LINES

Number of control cell lines undicated in parenthesis Mean $\pm 1 \mathrm{~S} D$ based on at least three determinations of each cell line Total adenosine deaminating actinty (ADA) in lymphoblast cell extracts was assayed using $\left[{ }^{14} \mathrm{C}\right]$ adenosune $(2 \mathrm{mC} / \mathrm{mmol})$ at a final concentration of $4 \mathrm{mM}$ EHNA-insensitve adenosine deaminating activity was determined using $4 \mathrm{mM} i^{14} \mathrm{C}$ ] adenosine $(2 \mathrm{mCl} / \mathrm{mmol})$ with $200 \mu \mathrm{M}$ EHNA Adenosine deamunase activity was considered to represent the difference of the total activity and the EHNA-Insensitive am inohydrolase activity

\begin{tabular}{|c|c|c|c|}
\hline \multirow[t]{2}{*}{ Lymphoblast cell lunes } & \multicolumn{3}{|c|}{ Adenosine deamunating activity ( $\mathrm{nmol} / \mathrm{min}$ per $\mathrm{mg}$ ) } \\
\hline & Total & $\begin{array}{l}\text { EHNA-Insensitive } \\
\text { amunohydrolase }\end{array}$ & $\begin{array}{l}\text { Adenosine deaminase } \\
\text { (Total minus EHNA- } \\
\text { insensitive activity) }\end{array}$ \\
\hline Normal (6) & $7269 \pm 1548$ & $026 \pm 017$ & 7243 \\
\hline \multicolumn{4}{|l|}{ ADA-deficient } \\
\hline GM 2294 & $2530 \pm 114$ & $058 \pm 002$ & 2472 \\
\hline GM 2756 & $053 \pm 002$ & $049 \pm 002$ & 004 \\
\hline GM 2471 & $040 \pm 001$ & $029 \pm 001$ & 011 \\
\hline GM 2606 & $033 \pm 002$ & $032 \pm 001$ & 001 \\
\hline GM 2445 & $200 \pm 010$ & $193 \pm 005$ & 007 \\
\hline
\end{tabular}

ultracentrifugation, dialyzed and reapplied to a further sucrose gradient, the enzyme actuvity was invanably present as a single peak with an $s_{20, w}$ of $7.4 \mathrm{~S}$. This EHNA-insensitive aminohydrolase activity showed no evidence of dissociation to a species of $s_{20, w} 3.8 \mathrm{~S}$.

Additional cultured B-lymphoblast cell lines from normal and adenosine deaminase-deficient subjects were analyzed for adenosine deaminating activity. As shown in Table I, the level of total adenosine deaminating activity in adenosine deaminase-deficient B-lymphoblast cell lines varied from 05 to $35 \%$ of normal. In four of the five mutant cell lines studied, the vast majonty of the adenosine deaminating activity present was the EHNA-insensitive aminohydrolase. In addition, the level of EHNA-Insensitive aminohydrolase activity in four of the five mutant cell lines overlapped the range noted in six cell lines derived from adenosine deaminase positive individuals.

Normal lymphoblast adenosine deaminase (small-form, $s_{20, w} 38 \mathrm{~S}$ ) 1solated from sucrose gradients was incubated with a 100 -fold molar excess of adenosune deaminase-binding protein, and subjected to sucrose gradient ultracentrifugation. The resulting enzyme activity profile revealed complete conversion of the small-form adenosine deaminase to the large molecular form of the enzyme $\left(s_{20, w} 10.0 \mathrm{~S}\right)$ (Fig. 2A). Under the conditions of this experiment, no detectable EHNA-Insensitive aminohydrolase activity was observed. Using the same expenmental conditions, lymphoblast EHNA-Insensitıve amınohydrolase $\left(s_{20, w} 74 \mathrm{~S}\right)$ ssolated from sucrose gradients was also incubated with a 100 -fold excess of adenosine deaminse-binding protein. The EHNA-insensitive aminohydrolase isolated from either normal or adenosine deaminase-deficient lymphoblasts could not be converted to a species of higher $s_{20, w}$ as observed with normal small-form adenosine deaminase ( $\mathrm{F} 1 \mathrm{~g}$. $2 \mathrm{~B}$ ). 

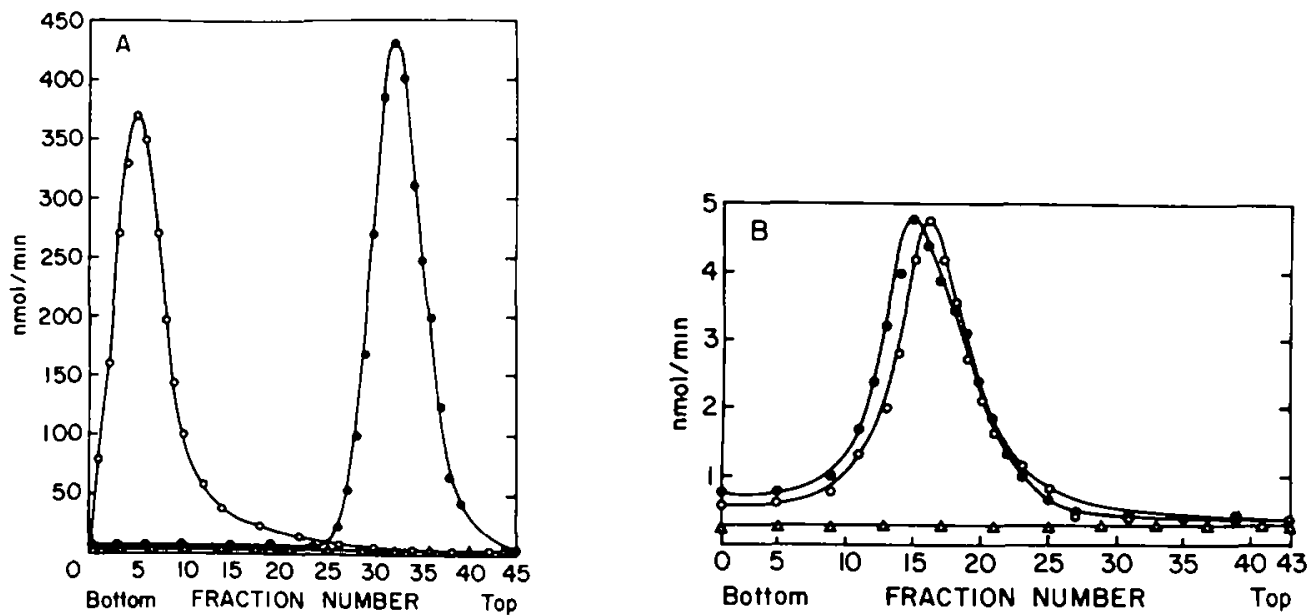

Fig 2 Interaction of adenosine deaminase and the EHNA-insensitive aminohydrolase with adenosine deamınase-binding protein A Lymphoblast adenosine deaminase isolated from sucrose gradients (3200 $\mathrm{nmol} / \mathrm{min}$ ) was incubated for $20 \mathrm{~min}$ at $37^{\circ} \mathrm{C}$ with $05 \mathrm{mg}$ bovne serum albumin $(\bullet-\longrightarrow)$ or with 05 mg punfied adenosine deaminase-binding protein prepared as descnbed in Methods (O- $\longrightarrow$ ) Punfied adenosine deaminase-binding protein was incubated alone as above $(\triangle \longrightarrow-\Delta)$ B Lymphoblast EHNAinsensitive aminohydrolase isolated from sucrose gradients ( $35 \mathrm{nmol} / \mathrm{min}$ ) was incubated as above with $05 \mathrm{mg}$ bovine serum albumin $(\bullet \longrightarrow)$ or with $05 \mathrm{mg}$ adenosine deaminase-binding protein $(\circ \longrightarrow-\infty)$ Punfied adenosine deamınase-bındıng protein was incubated alone $(\Delta \longrightarrow \longrightarrow \triangle)$ All incubation mix tures were centnfuged into separate sucrose gradients

The physical and kinetic properties of the EHNA-insensitive aminohydrolase solated from normal and adenosine deaminase-deficient lymphoblast cell lines and normal small-form lymphoblast adenosine deaminase are summanzed in Table II. The EHNA-insensitive aminohydrolase has an $s_{20, w}$ of $7.46 \pm 0.18 \mathrm{~S}$ (mean \pm S.D., 11 determinations) with a calculated mean molecular weight of 110000 , whlle small-form adenosine deaminase has an $s_{20, w}$ of $3.8 \pm 0.02 \mathrm{~S}$ (mean \pm S.D., five determinations) with a calculated mean molecular weight of 38000 . The EHNA-insensitive aminohydrolase has; (a) a sharp pH optımum of 5.5- 6.0 as compared to the higher broad $\mathrm{pH}$ optımum of adenosine deammase,

TABLE II

CHARACTERISTICS OF THE MOLECULAR FORMS OF ADENOSINE DEAMINATING ACTIVITY IN LYMPHOBLASTS

Extracts trom normal lymphoblasts and adenosne deaminase-deficient lymphoblasts were subjected to sucrose gradient ultracentrufugation Peak fractions corresponding to the EHNA-insensitive aminohydrolase were isolated as described in Methods Adenosine deaminase was isolated from normal lymphoblasts in a similar manner Numbers in parenthesis indicate the number of determinations All other values reported represent the average of two determinations

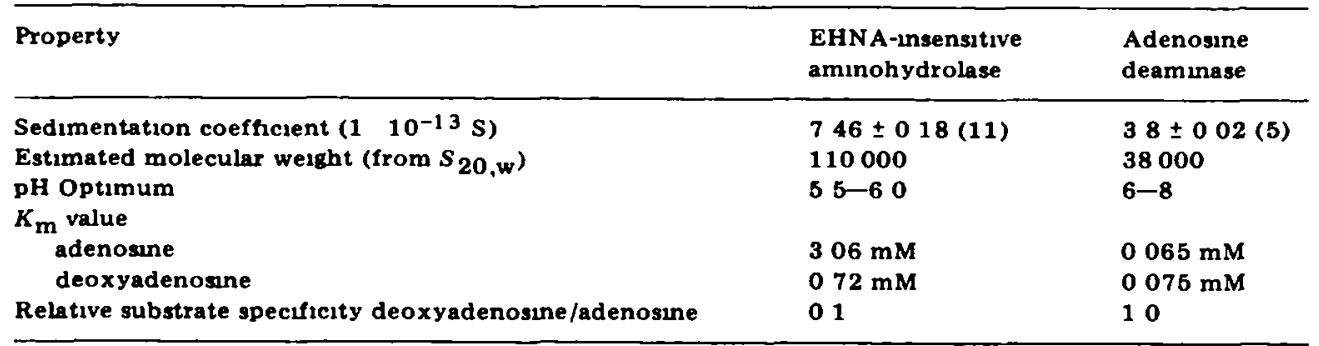


(b) a markedly elevated $K_{\mathrm{m}}$ value for adenosine $(3.06 \mathrm{mM})$ and deoxyadenosine $(0.72 \mathrm{mM})$ as compared to the $K_{\mathrm{m}}$ value of adenosine deaminase with these two substrates ( 0.065 and $0.075 \mathrm{mM}$, respectively), and (c) a lower rate of catalytic activity with the substrate deoxyadenosine, as compared to that with adenosine, than noted with adenosine deaminase.

The heat stability of adenosine deaminating activity is shown in Fig. 3. Under the conditions of our study, adenosine deaminase exhibited a logarithmic decay of enzyme activity at $68^{\circ} \mathrm{C}$ with a $t_{1 / 2}$ of approx. $30 \mathrm{~min}$, while the EHNA-Insensitive aminohydrolase activity was reduced by less than $5 \%$ over the 90 min incubation penod. During the time course of adenosine deaminase heat inactivation, no EHNA-insensitive aminohydrolase actinty was generated.

The effect of divalent cations on adenosine deaminating catalytic activity is shown in Table III. Of the divalent cations tested, only iron and nickel selectively inhibited normal adenosine deaminase.

The relative substrate specificity of the EHNA-insensitive aminohydrolase was compared to adenosine deaminase as shown in Table IV. The potential substrates, AMP, dAMP, ADP, dADP, ATP, dATP, cytıdıne, cytosıne, deoxycytıdine, CMP, dCMP, CDP, dCDP, CTP, dCTP, guanine, guanosine, deoxyguanosine, undine and deoxyurine, did not compete with the conversion of adenosine to inosine whether catalyzed by adenosine deaminase or the EHNA-Insens1tive aminohydrolase under the conditions of our study. However as shown in Table IV, adenıne, 6-chloropunne and 2,6-diaminopurine reduced the deamination of adenosine to inosine when catalyzed by the EHNA-Insensitive aminohydrolase whlle $N$-carbamyl- $\beta$-alanine and 6-methylaminopurne rboside reduced the deamination of adenosine when catalyzed by adenosine deaminase. A further differential effect was observed with the competitive adenosine deaminase inhibitors. While the EHNA-Insensitive aminohydrolase was relatively insensitive to the adenosine deaminase inhibitor, EHNA, it was completely inhibited by 2 '-deoxycoformycin simlar to adenosine deaminase. Using

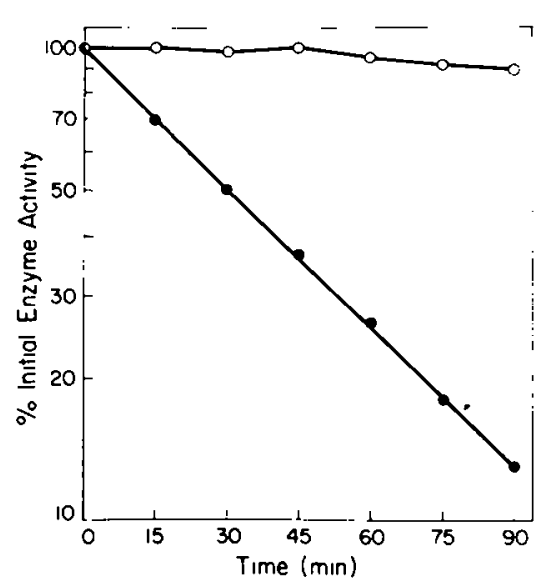

Fig 3 Heat stability of adenosine deaminating activity Lymphoblast cell lysates (protein concentratuon, $2 \mathrm{mg} / \mathrm{ml}$ ) were incubated at $68^{\circ} \mathrm{C}$ in buffer $A$ for various times Extract of MgL-8 contanung normal adenosine deaminase $(\bullet-\longrightarrow)$ Extract of GM 2445 containing exclusively EHNA-Insensitive aminohydrolase actunity $(\mathrm{O} \longrightarrow 0)$ (see Fig 1B) 


\section{TABLE III}

\section{SENSITIVITY OF LYMPHOBLAST ADENOSINE DEAMINATING ACTIVITY TO INHIBITION BY DI- VALENT CATIONS}

All divalent cations were used as their chloride salts at a final concentration of $25 \mathrm{mM}$ The EHNA-insensitive aminohydrolase and adenosine deaminase were isolated from sucrose gradients and were assayed using $K_{\mathrm{m}}$ concentrations of adenosine in the presence of divalent cations The EHNA-insensitive aminohydrolase and adenosine deaminase were assayed using $\left[8{ }^{14} \mathrm{C}\right]$ adenosine $\left(2 \mu \mathrm{C}_{1} / \mu \mathrm{mol}\right)$ at final adenosine concentrations of $4 \mathrm{mM}$ and $01 \mathrm{mM}$, respectively Results are expressed as a percentage of inhibition compared to the control with only buffer added

\begin{tabular}{lll}
\hline Cation & \multicolumn{2}{l}{ Percent inhibition of adenosine deaminating activity } \\
\cline { 2 - 3 } & $\begin{array}{l}\text { EHNA-insensitive } \\
\text { arrinohydrolase }\end{array}$ & Adenosine deaminase \\
\hline Iron & 0 & 71 \\
Nickel & 4 & 76 \\
Magnesium & 16 & 10 \\
Manganese & 23 & 48 \\
Calcium & 25 & 18 \\
Mercury & 94 & 97 \\
Cadmium & 76 & 96 \\
Cobalt & 30 & 56 \\
Copper & 96 & 98 \\
Barium & 14 & 5 \\
Zinc & 93 & 98 \\
\hline
\end{tabular}

\section{TABLE IV}

\section{APPARENT SUBSTRATE SPECIFICITY OF LYMPHOBLAST ADENOSINE DEAMINATING AC- TIVITY}

The final concentration of each substrate tested was $25 \mathrm{mM}$ with the exception of EHNA and $2^{\prime}$-deoxycoformycin whuch were used at final concentrations of $200 \mu \mathrm{M}$ and $20 \mu \mathrm{M}$, respectively All solutions were prepared in $50 \mathrm{mM}$ Tris $\mathrm{HCl}, \mathrm{pH} 7 \mathrm{4}$, on the day of the study The EHNA-insensitive aminohydrolase and adenosine deaminase were isolated from sucrose gradients and were assayed using $K_{m}$ concentrations of adenosine in the presence of various compounds The EHNA-insensitive aminohydrolase and adenosine deaminase were assayed using $\left[8-{ }^{14} \mathrm{C}\right]$ adenosine $\left(2 \mu \mathrm{C}_{1} / \mu \mathrm{mol}\right)$ at final adenosine concentrations of $4 \mathrm{mM}$ and $01 \mathrm{mM}$, respectively Results are expressed as a percentage of inhibition compared to the control with only buffer added

\begin{tabular}{|c|c|c|}
\hline \multirow[t]{2}{*}{ Compound } & \multicolumn{2}{|c|}{ Percent inhibition of deaminating activity } \\
\hline & $\begin{array}{l}\text { EHNA-insensitive } \\
\text { aminohydrolase }\end{array}$ & Adenosine deamunase \\
\hline Adenine & 75 & 51 \\
\hline$N$-Carbamyl- $\beta$-alanine & 0 & 78 \\
\hline 6-Methylamunopurine riboside & 42 & 88 \\
\hline 4-Amino-5-1midazole carboxamıde- $\mathrm{HCl}$ & 47 & 42 \\
\hline 6-Chloropunne rboside & 18 & 24 \\
\hline 6-Chloropyrine & 70 & 15 \\
\hline 6-Methyl mercaptopurine riboside & 25 & 55 \\
\hline Cordycepin (3'-deoxyadenosine) & 51 & 90 \\
\hline 2.6-Diamunopurine & 99 & 8 \\
\hline 5-Adenosyl homocysteme & 12 & 8 \\
\hline Homocysteine thiolactone & 9 & 7 \\
\hline EHNA & $\mathbf{8}$ & 98 \\
\hline 2'-Deoxycoformycun & 99 & 99 \\
\hline
\end{tabular}


specific radioactive-labeled substrates and established radiochemical assay procedures, neither the EHNA-insensitive aminohydrolase nor adenosine deaminase were able to catalyze the deamination of guanıne, adenine, AMP or cytıdine.

The possibulity that this EHNA-insensitive aminohydrolase actinty reflected an aggregated or denatured form of adenosine deaminase was examined further by a radioimmunochemical assay. Ecuivalent activities of lymphoblast adenosine deaminase and EHNA-insensitive ammohydrolase, 10, 5.0 and $2.5 \mathrm{nmol} /$ min per ml of each respectively, were assayed with a previously described competitive adenosine deaminase radioimmunoassay [24]. Under the conditions of this assay, the least detectable quantity of adenosine deaminase was equivalent to $0.17 \mathrm{nmol} / \mathrm{min}$ per $\mathrm{ml}$ or $0.3 \mathrm{ng} / \mathrm{ml}$. Using the radioimmunoassay, the dilutions of lymphoblast adenosine deaminase showed a normal competition for antibody binding similar to the adenosine deaminase standard used in the assay (slope -1.0 ) and were found to be completely cross-reactive (greater than 99\%). When the same dilutions of EHNA-insensitive aminohydrolase activity were assayed, virtually undetectable levels of adenosine deaminase protein (1.e., less than $1 \%$ immunoreactive material relative to normal adenosine deaminase) were observed. In a similar manner both lymphoblast adenosine deaminase and the EHNA-Insensitive aminohydrolase were assayed for the presence of the adenosine deaminase-bınding protem using a prevously described radioimmunoassay technique [22]. In both cases the level of adenosine deaminasebinding protein was virtually undetectable (less than $0.5 \mathrm{ng} / \mathrm{ml}$ ). These data suggested that the EHNA-insensitive aminohydrolase did not share any ant1genic determinants in common with normal adenosine deaminase and further was not associated or complexed with the adenosine deaminase-binding protein in lymphoblast cell lines.

\section{Discussion}

In this study we have demonstrated the presence of an EHNA-insensitive aminohydrolase in both normal and adenosine deaminase-deficient B-lymphoblast cell lines which is similar if not identical with a previously reported splenic 'aminohydrolase' [21]. Further characterization of the enzymatic, physical, and immunoreactive properties of this aminohydrolase suggests that this enzyme is not related to adenosine deaminase and is most probably coded for by a different gene locus than adenosine deaminase.

Analysis of adenosine deaminating activity in both normal and adenosine deaminase-deficient lymphoblast cell lines revealed the presence of low but similar levels of EHNA-insensitive aminohydrolase activity. With the exception of cell line GM 2294, the adénosine deaminating activity in all adenosine deaminase-deficient cells was almost completely EHNA-insensitive indicating the presence of an EHNA-Insensitive aminohydrolase similar to that reported by Schrader et al. [21] in spleen. Cell line GM 2294, with $35 \%$ of normal adenosine deaminating activity, was obtaned from an immunologically normal, healthy subject with severe erythrocyte adenosine deaminase deficiency [26]. However, even in this patient's lymphoblasts, the level of the EHNA-insensitive aminohydrolase was still comparable to that in all other adenosine deaminase 
deficient as well as the normal cell lines analyzed. These data suggest that the level of adenosine deaminase activity does not apparently regulate the level of the EHNA-insensitive aminohydrolase activity in lymphoblasts.

The EHNA-insensitive aminohydrolase present in both normal and adenosine deaminase-deficient B-lymphoblast cell lines appears to be simlar if not ident1cal to the 'aminohydrolase' activity described in spleen. Schrader et al. [21], reported that the splenic 'aminohydrolase' had an estımated molecular weight of 92000 and did not appear to cross-react with anti-adenosine deaminase serum (1mmobilized to Sepharose). In our studies we have demonstrated that the lymphoblast EHNA-Insensitive aminohydrolase has a molecular weight of 110000 and showed less than $1 \%$ cross-immunoreactivity relative to normal adenosine deaminase. Further, it did not contain an adenosine deaminase-binding protein component (less than $1 \%$ ) using sensitive and specific radioimmunoassays. The $\mathrm{pH}$ optımum (6.5), $K_{\mathrm{m}}$ values for adenosine $(2 \mathrm{mM})$, insensitivity to EHNA, and inhibition by adenine reported for the splenic 'ammohydrolase' compare well to our findings for the lymphoblast EHNA-insensitive aminohydrolase. In addition, we have examined other properties of this lymphoblast aminohydrolase which would serve to distinguish it from adenosine deaminase such as, its $K_{\mathrm{m}}$ value for deoxyadenosine, sensitivity to heavy metals, heat stability, relative substrate specificity, interaction with the adenosine deamlnase-binding protein, and sensitivity to another potent competitive adenosine deaminase inhibitor, deoxycoformycin.

Relative to adenosine deaminase, the EHNA-insensitive aminohydrolase activity in all lymphoblast cell lines had a high $K_{\mathrm{m}}$ value for the substrates adenosine and deoxyadenosine suggesting that this enzyme might be more active with other more specific substrates. However, in our study of apparent substrate specificity only selected purine bases were found to markedly compete with the substrate adenosine and of those compounds tested, none appeared to be deaminated. With respect to adenosine and purne metabolism in general, we found that the EHNA-Insensitive aminohydrolase isolated from sucrose density gradients did not deaminate guanine, cytidine, AMP or adenıne nor did it have enzymatic activity of S-adenosyl homocysteme hydrolase. The functional significance of this aminohydrolase thus still remains to be established.

We have considered the possibility that this low level of EHNA-insensitive aminohydrolase activity in lymphoblasts may be related to adenosine deamlnase and may possibly represent denaturated or aggregated product(s) of normal adenosine deaminase protein degradation. However, the level of the EHNAinsensitive aminohydrolase activity in 11 different, actively growing lymphoblast cell lines was apparently independent of the level of adenosine deaminase (see Table I). In addition heat denaturation of normal adenosine deaminase falled to produce EHNA-insensitive aminohydrolase type activity. Further, the EHNA-Insensitive aminohydrolase showed less than $1 \%$ cross-immunoreactivity relative to normal adenosine deaminase and fauled to show any interaction with the adenosine deaminase-binding protein. These data taken together strongly suggest that the lymphoblast aminohydrolase is not related to adenosine deamunase and is coded for by a different gene locus than that coding for adenosine deaminase. 
The presence of this low level of EHNA-Insensitive aminohydrolase activity described in lymphoblasts may be a universal finding in a vanety of normal human tissues. Therefore, in future investigations designed to charactemze the low level of residual adenosine deaminase in patients with adenosine deficiency and severe combined immunodeficiency disease, it will be important to either exclude the presence of this EHNA-Insensitive aminohydrolase activity or be able to distinguish it from a putative altered product of the adenosine deaminase gene locus. In our study we have presented several distınguishing characteristics of the EHNA-Insensitive aminohydrolase and adenosine deaminase for this purpose.

\section{Acknowledgements}

The authors would like to express their appreciation to Susan B. Strikwerda for her fine technical assistance. This research was supported by the National Foundation March of Dimes Research Grant, 1-393, National Institute of Health Grant, AM 19045, and the National Cancer Instıtute Grant, CA 26284.

\section{References}

1 Gıblett, E. R, Anderson, J E, Cohen, F, Pollara, B and Meuwissen, H J (1972) Lancet 2, 10671069

2 Dissing, J and Knudsen, B (1972) Lancet 2, 1316

3 Coleman, M D , Donofno, J, Hutton, J, Hahn, L, Daoud, A , Lampkin, B and Dyminsku, J (1978) $J$ Biol Chem 253, 1619-1626

4 Cohen, A . Hirschhorn, R, Horowitz, S D, Rubinstein, A, Polmar, S H, Hing, R and Martın, D W (1978) Proc Natl Acad Sc1 U S A 75, 472-476

5 Mitchell, B S. Mejıas, E, Daddona, PE and Kelley. W N (1978) Proc Natl Acad Sci U S A 75 , $5011-5014$

6 Wison, J M , Mitchell, B S , Daddona, P E and Kelley, W N (1979) J Clin Invest 64, 1475-1484

7 Spencer, $N$, Hopkinson, $D A$ and Hams, $H$ (1968) Ann Hum Genet 32, 9-14

8 Osborne, W R A and Spencer, N (1973) Biochem J 133, 117-123

9 Edwards, Y H , Hopkınson, D A and Harns, H (1971) Ann Hum Genet (London) 35, $207-219$

10 Van der Weyden, M B and Kelley, W N (1976) J Biol Chem 252,5448-5456

11 Hopkinson, D A and Harns, $H$ (1969) Ann Hum Genet 33,81-87

12 Hirschhorn, $R$ (1975) $\mathrm{J}$ Clin Invest $55,661-667$

13 Nishihara, H, Ishikawa, S, Shinka, $K$ and Akedo, H (1972) Biochem Biophys Acta $302,429-442$

14 Schrader, W P, Stacy, A R and Pollara, B (1976) J Biol Chem 251, 4026-4032

15 Daddona, P E and Kelley, W N (1977) J Biol Chem 252, 110-115

16 Daddona, P E and Kelley, W N (1979) Biochim Brophys Acta 580, 302-311

17 Daddona, $P$ E and Kelley, W N (1978) J Biol Chem 253,4617-4623

18 Schradex, W $P$ and Stacy, A R (1977) J Biol Chem 252,6409-6415

19 Swallow, D M , Evans, L and Hopkinson, D A (1977) Nature 269, 261-262

20 Van der Weyden, M D. Buckley, R H and Kelley, W N (1974) Biochem Brophys Res Commun 57 . $590-595$

21 Schrader, W P. Pollara, B and Meuwissen, H J (1978) Proc Natl Acad Sc1 U S A 75, 446-450

22 Daddona, P E. Frohman, $M A$ and Kelley. W N (1979) J Brol Chem 255, 5681-5687

23 McCarty, K S , Stafford, D and Brown, $O$ (1968) Anal Biochem 24, 314-329

24 Daddona, P E , Frohman, $M A$ and Kelley, W N (1979) J Clin Invest 64, 798-803

25 Lowry, O H Rosebrough, N J , Farr, A L and Randall, R J (1951) J Biol Chem 193, 265-275

26 Hurschhorn, R, Roegnex, V , Jenkins, T, Seaman, C, Plomell, S and Borkowsky, W (1979) J Clin Invest $64,1130-1139$ 